\title{
PERAN KEUNGGULAN KOMPETITIF MEMEDIASI PENGARUH GREEN MARKETING TERHADAP KEPUTUSAN PEMBELIAN (Studi Pada Perusahaan Earth Café di Seminyak)
}

\author{
Ida Bagus Ivan Satria Widiarsa ${ }^{1}$ \\ Eka Sulistyawati ${ }^{2}$
}

${ }^{1}$ Fakultas Ekonomi dan Bisnis Universitas Udayana (Unud), Bali, Indonesia e-mail: satriaivan@ rocketmail.com

\begin{abstract}
ABSTRAK
Tujuan penelitian ini ialah peran keunggulan kompetitif memediasi pengaruh green marketing terhadap keputusan pembelian (Studi Kasus pada Perusahaan Earth Cafe di Seminyak). Penelitian ini dilakukan di Earth Cafe di Seminyak dengan teknik analisis data path analisa. Jumlah sampel yang didapat dengan menggunakan metode random sampling ialah sebanyak 90 responden. Berdassarkan hasil analisis dapat diketahui Green marketing berpengaruh signifikan terhadap keunggulan kompetitif. Green marketing berpengaruh signifikan terhadap keputusan pembelian. Keunggulan kompetitif berpengaruh signifikan terhadap keputusan pembelian. Keunggulan kompetitif memediasi pengaruh green marketing terhadap keputusan pembelian pada Earth Cafe Seminyak.
\end{abstract}

Kata kunci : green marketing, keunggulan kompetitif, keputusan pembelian

\begin{abstract}
The purpose of this study is the role of competitive advantage mediate the influence of green marketing on purchasing decisions (Case Study at Earth Cafe Company in Seminyak). This research was conducted at Earth Cafe in Seminyak with analytical data path analysis technique. The number of samples obtained by using random sampling method is as much as 90 respondents. Based on the analysis results can be known Green marketing has a significant effect on competitive advantage. Green marketing has a significant effect on purchasing decisions. Competitive advantage significantly affects purchasing decisions. Competitive advantage mediates the influence of green marketing on purchasing decisions at Earth Cafe Seminyak.
\end{abstract}

Keywords: green marketing, competitive advantage, purchase decision 
Ida Bagus Ivan Satria Widiarsa, Peran Keunggulan Kompetitif Memediasi Pengaruh...]

\section{PENDAHULUAN}

Sejak beberapa dekade terakhir kesadaran masyarakat dunia akan pentingnya pelestarian lingkungan semakin meningkat, peningkatan ini dicetuskan oleh adanya kekhawatiran besar kemungkinan terjadinya bencana lingkungan hidup yang mengancam, bukan hanya kesehatan, namun bahkan sampai pada kelangsungan hidup manusia dan keturunannya. Bukti-bukti yang ditunjukan para ilmuwan dan pemerhati lingkungan, seperti penipisan lapisan ozon yang secara langsung memperbesar prevelensi kanker kulit dan berpotensi mengacaukan iklim dunia serta pemanasan global, memperkuat alasan kekhawatiran tersebut. Belum lagi masalah hujan asam, efek rumah kaca, polusi udara dan air yang sudah pada taraf berbahaya, kebakaran dan penggundulan hutan yang mengancam jumlah oksigen di atmosfir kita dan banjir di sejumlah kota. Sampah sekarang menjadi masalah besar karena jumlah sampah yang semakin besar dan banyaknya sampah yang sulit di daur ulang (Wibowo B., 2002).

Green consumerism adalah kelanjutan dari gerakan konsumerisme global yang dimulai dengan adanya kesadaran konsumen akan hak-haknya untuk mendapatkan produk yang layak, aman, dan produk yang ramah lingkungan (environment friendly) yang semakin kuat. Produk yang diinginkan bukan yang benar-benar 'hijau', namun mengurangi tingkat kerusakan yang ditimbulkan.

Adanya kesadaran tersebut maka perusahaan menerapkan isu-isu lingkungan sebagai salah satu strategi pemasarannya atau yang telah kita kenal sebagai green marketing. Hal ini juga sesuai dengan meningkatnya perhatian pada isu lingkungan oleh pembuat peraturan publik dapat dilihat 
sebagai indikasi lain bahwa kepedulian lingkungan merupakan area yang potensial sebagai strategi bisnis (Menon \& Menon,1997). Pada penelitian yang dilakukan oleh Byrne (2002) dikatakan bahwa environmental atau green marketing (pemasaran hijau) merupakan fokus baru dalam usaha bisnis, yaitu sebuah pendekatan pemasaran stratejik yang mulai mencuat dan menjadi perhatian banyak pihak mulai akhir abad 20 (Ottman, 1998). Kondisi seperti ini menuntut pemasar untuk hati-hati ketika keputusan yang diambil melibatkan lingkungan.Perhatian terhadap isu-isu lingkungan terlihat nyata dari meningkatnya pasar yang peduli lingkungan (Laroche et al., 2001).

Green marketing merupakan topik yang banyak dibicarakan di masyarakat pada saat ini. Banyak perusahaan yang berpendapat bahwa green marketing merupakan sebuah ide yang bagus dan berpotensi untuk kedepannya serta menerapkan sistem pemasaran green marketing guna untuk meningkatkan penjualan. Green marketing perlu diterapkan pada dunia pemasaran dikarenakan adanya ketertarikan para konsumen mengenai kepedulian terhadap lingkungan. Kondisi dunia adalah bukti menunjukkan orang yang peduli lingkungan dan mengubah perilaku mereka. Green marketing saat ini merupakan peluang besar untuk menerapkan strategi-startegi pemasaran terbaru. Green marketing menjadikan biaya-biaya produksi lebih efisien karena merupakan program daur ulang produk. Selain itu, perilaku masyarakat untuk melestarikan lingkungan menjadi dasar penting untuk melakukan green marketing sehingga pemasar dapat lebih mudah melakukan startegi-strateginya (Rizky, 2013, p.48). 
Ida Bagus Ivan Satria Widiarsa, Peran Keunggulan Kompetitif Memediasi Pengaruh...]

Ketika beberapa perusahaan menggunakan green marketing sebagai poros strategi pemasarannya yang sukses, maka mulai saat itu green marketing mulai menjadi fokus utama bisnis bagi berbagai perusahaan. Banyak pula perusahaan yang hanya memandang green marketing hanya sebagai strategi pemasaran minor, bahkan hanya menjadi strategi niche pada pasar (Fuller, 1999). Green marketing dianggap gagal oleh beberapa peneliti lain dalam memberikan kontribusi lebih lanjut pada isu lingkungan dan pengintegrasian potensi keunggulan bersaing dengan kepedulian lingkungan sebagai strategi bisnis (Vlosky et al, 1999 dalam Byrne, 2002). Jika isu lingkungan memiliki arti penting bagi konsumen dalam memilih produk, dan jika suatu perusahaan di dalam pasar menjadi satu-satunya yang memberi tawaran dengan suatu bauran pemasaran lingkungan di antara para pesaingnya, maka perusahaan akan memiliki sisi strategic competitive advantage yang tinggi (Cravens et al., 2000).

Pada era persaingan yang semakin ketat ini, salah satu cara mendapatkan pelanggan adalah dengan memuaskan kebutuhan konsumen dari waktu ke waktu. Sering kali perusahaan berlomba-lomba menyediakan produk dengan harga yang murah dengan anggapan konsumen hanya mempertimbangkan harga dalam keputusan pembelian. Anggapan ini tidak sepenuhnya benar. Berbagai teori perilaku pelanggan dan pemasaran menyatakan bahwa kebutuhan manusia tidak saja dipengaruhi oleh motivasinya, melainkan juga hal-hal eksternal, seperti budaya, sosial, dan ekonomi. Keputusan pembelian dan pilihan produk seringkali dipengaruhi oleh dorongan-dorongan yang sifatnya psikologis. Produk memang tidak dirancang untuk memenuhi kebutuhan fungsionalnya saja, namun 
juga memuaskan kebutuhan sosial dan psikologi. Green marketing merujuk pada kepuasan kebutuhan, keinginan, dan, hasrat pelanggan dalam hubungan dengan pemeliharaan dan pelestarian dari lingkungan hidup.

Earth Cafe beroperasi mengkhususkan penjualan makanan berbasis green produk. Dua tahun belakangan ini Earth Cafe mengalami masalah terhadap kepuasan konsumen, yang dirasakan melalui tingkat pertumbuhan penjualan yang belum memadai akibat rendahnya tingkat pertumbuhan kunjungan konsumen. Perkembangan kunjungan konsumen pada Earth Café pada dua tahun terakhir terjadi penurunan jumlah kunjugan konsumen dimana pada tahun 2015 sebesar (15) persen dan 2016 terjadi penurunan lagi sebesar $(-17,6)$ persen.

Earth Café di seminyak merupakan restoran yang sudah terkenal di dunia kuliner dan merupakan salah satu dari pelopor dari green marketing. Di Bali banyak restoran akan tetapi yang berbasis green marketing jumlahnya sedikit, artinya para konsumen dihadapkan pada banyaknya pilihan yang menyebabkan mereka bingung untuk memilih, karena jika salah memilih dapat berakibat fatal bagi kesehatan mereka. Apa yang ditawarkan oleh Earth Café di Seminyak agak berbeda karena menawarkan produk dengan bahan-bahan alami dan ramah lingkungan. Prinsip dasar ramah lingkungan yang dimiliki yaitu fresh, berbahan dasar organic yang mengarahkan bisnis untuk mengukur keberhasilan dari tiga pilar pendukungnya yaitu profit, people dan planet. Dengan demikian profit bukan satu-satunya sumber energi bagi kelangsungan hidup sebuah perusahaan. Tanpa memperhitungkan people (aspek sosial) dan planet (aspek lingkungan), sebuah perusahaan tidak akan pernah dapat melanjutkan hidupnya. 
Ida Bagus Ivan Satria Widiarsa, Peran Keunggulan Kompetitif Memediasi Pengaruh...]

Harus diakui, pendekatan ini masih harus menempuh perjalanan panjang untuk dapat menjadi etika berbisnis disetiap perusahaan.Pada konteks green marketing, konsumen akan menilai produk makanan organik yang memperhatikan aspek lingkungan. Perusahaan harus berupaya mempertahankan pelayanan yang memadai ataupun meningkatkan pelayanannya.

Sulistyandari dan Sri (2013), menyebutkan bahwa keunggulan kompetitif merupakan alat dalam pencapaian tujuan keuangan organisasi untuk mendapatkan keberhasilan melebihi para pesaingnya. Keunggulan kompetitif merupakan fungsi identifikasi dimensi produk pasar yang tepat bagi posisi perusahaan. Porter (1985) menyatakan bahwa keunggulan kompetitif sebagai upaya penciptaan nilai pelanggan yang lebih baik dibandingkan pesaingnya dengan cara melakukan aktivitas-aktivitas spesifik secara ekonomis ataupun kualitas superior / pelayanan ataupun kombinasi keduanya dibandingkan dengan para kompetitornya. Barney (1991) menjelaskan bahwa karakteristik sumber daya yang bernilai bagi keunggulan bersaing adalah yang berkaitan dengan sumber daya yang bernilai, kompleks, eksklusif, mudah digeneralisasi, dan susah ditiru pesaing. Pada perspektif tersebut keunggulan kompetitif strategis diperoleh dari sumber daya inti (core resources) dan kompetensi inti (core competence) yang bernilai, langka, susah ditiru, dan tidak ada penggantinya (substitutability). Kemampuan dan sumber daya dikatakan substitutability dalam dua arti, pertama tidak dapat ditiru atau justru dapat menggantikan sumber daya sejenis yang dimiliki pesaing (Barney, 1991). Penting bagi organisasi untuk bisa membuat produknya susah ditiru ataupun menggeser milik pesaing (Sulistyandari dan Sri, 2013:2-3). 
Berdasarkan pembahasan tersebut banyak faktor yang bisa menciptakan keunggulan kompetitif. Faktor-faktor yang akan dipaparkan untuk menciptakan keunggulan kompetitif yakni salah satunya adalah green marketing sehingga menimbulkan niat dalam pengambilan keputusan pembelian dikalangan konsumen dan dikaitkan dengan isu-isu lingkungan saat ini guna mengurangi polusi yang menyebabkan kerusakan lingkungan.

Ruyatnasih, dkk. (2013) menyebutkan keputusan pembelian merupakan keputusan konsumen untuk memutuskan membeli atau mengkonsumsi produk tertentu akan diawali oleh langkah-langkah yaitu pengenalan kebutuhan, waktu, perubahan situasi, pemilikan produk, konsumsi produk, perbedaan individu, pengaruh pemasaran,pencarian informasi, pencarian internal, dan pencarian eksternal. Shareef et al. (2008) perilaku pembelian mendapatkan banyak perhatian dari pemasar karena peran signifikan yang dimainkannya dalam mengantisipasi keberhasilan operasional dan mencapai keunggulan kompetitif yang berkelanjutan. Keputusan pembelian dapat didefinisikan sebagai proses yang berkesinambungan, yang mengacu pada konsistensitindakan yang bijaksana dan dilakukan untuk membawa kepuasan dalam kebutuhan. Umumnya, konsumen cukup rasional dan memanfaatkan sistemik dari informasi yang tersedia bagi konsumen. Keputusan pembelian dapat dilihat secara simbolis dalam hal respon emosional, kesenangan indera, dan pertimbangan estetika. Dari perspektif strategi pemasaran, menciptakan keputusan pembelian di konsumen berarti memenuhi kebutuhan sasaran pelanggan dan meningkatkan kepuasan yang dirasakan. Salah satu strategi yang dilakukan oleh marketing yaitu menerapkan strategi green 
Ida Bagus Ivan Satria Widiarsa, Peran Keunggulan Kompetitif Memediasi Pengaruh...]

marketing. Berdasarkan fenomena dan teori yang ada peneliti ingin menganalisis peran keunggulan kompetitif memediasi pengaruh green marketing terhadap keputusan pembelian pada Earth Café Seminyak.

Pemasaran hijau (green marketing) adalah proses penyusunan komunikasi terpadu yang bertujuan untuk memberikan informasi mengenai barang atau jasa dalam kaitannya dengan memuaskan kebutuhan dan keinginan manusia dengan cara yang sesuai untuk menjaga lingkungan. Berdasarkan Rachmawati (2011) dukungan faktor-faktor bauran pemasaran (marketing mix) mampu menciptakan nilai yang lebih bagi pelanggan yang berimbas kepada loyalitas pelanggan. Dengan adanya loyalitas pelanggan, maka akan mampu meningkatkan pendapatan pengusaha dibidang restaurant. Penelitian Risyamuka (2014) dalam penelitiannya menemukan pengaruh green marekting terhadap keputusan pembelian produk hijau di restoran Sari Organik Ubud. Penelitian yang relevan lainnya yaitu Netty Laura (2017) dalam penelitiannya menemukan pengaruh keunggulan produk dan keunggulan bersaing terhadap keputusan pembelian dengan citra merek sebagai vairabel intervening. Yani (2016) menyebutkan green marketing berpengaruh terhadap keunggulan produk organik pada Hero Supermarket Sidoarjo.

$\mathrm{H}_{1}$ : Green marketing berpengaruh signifikan terhadap keunggulan kompetitif.

Agustina, dkk. (2016) konsep pemasaran hijau mencakup karakteristik tertentu seperti pemasaran produk yang aman bagi lingkungan, pengembangan dan pemasaran produk yang dapat meminimalkan bahaya bagi lingkungan, memproduksi, mempromosikan, dan mengemas produk dengan cara yang sesuai sehingga dapat melindungi lingkungan. Pemasaran hijau terdiri dari berbagai 
kegiatan usaha yang bertujuan untuk memenuhi kebutuhan dan keinginan konsumen, serta mengurangi dampak negatif pada lingkungan alam.Pemasaran hijau dalam penerapannya di perusahaan mengadopsi empat elemen bauran pemasaran (marketing mix) antara lain: product, price, place, danpromotion. Keputusan pembelian salah satunya dipengaruhi oleh marketing mix yang dilakukan oleh perusahaan.Keputusan pembelian konsumen adalah membeli merek yang paling disukai. Pengambilan keputusan konsumen adalah suatu proses integrasi yang dipergunakan untuk mengkombinasikan pengetahuan dengan tujuan mengevaluasi dua atau lebih perilaku alternatif dan memilih satu diantaranya.

Berdasarkan penelitian dari Septifani,dkk. (2014) menyatakan bahwa teh dalam kemasan yang menerapkan konsep green marketing dengan menggunakan kemasan RGB (Returnable Glass Bottling) mampu meningkatkan keputusan pembelian konsumen yang memang sadar lingkungan.Berdasarkan pendapat tersebut, dapat disimpulkan bahwa keputusan pembelian merupakan penetapan pilihan konsumen melalui berbagai alternatif pilihan produk. Penelitian Risyamuka (2014) dalam penelitiannya menemukan pengaruh green marketing terhadap keputusan pembelian produk hijau di restoran Sari Organik Ubud. Yani (2016) menyebutkan green marketing berpengaruh terhadap keputusan pembelian produk organik pada Hero Supermarket Sidoarjo.

$\mathrm{H}_{2}$ : Green marketing berpengaruh signifikan terhadap keputusan pembelian.

Keunggulan kompetitif merujuk pada kemampuan sebuah organisasi untuk memformulasikan strategi yang menempatkannya pada suatu posisi yang 
Ida Bagus Ivan Satria Widiarsa, Peran Keunggulan Kompetitif Memediasi Pengaruh...]

menguntungkan dibandingkan perusahaan lainnya.Untuk meningkatkan keunggulan kompetitif dapat dilakukan dengan kebijakan harga yang kompetitif, promosi dan kualitas pelayanan.

Berdasarkan hasil penelitian Weenas (2013) menyatakan bahwa dengan meningkatkan kualitas pelayanan, promosi serta menerapkan harga yang terjangkau pada PT. Massindo Sinar Pratama dapat meningkatkan keputusan pembelian dari konsumen. Penelitian Risyamuka (2014) dalam penelitiannya menemukan pengaruh green marketing terhadap keputusan pembelian produk hijau di restoran Sari Organik Ubud. Penelitian yang relevan lainnya yaitu Netty Laura (2017) dalam penelitiannya menemukan pengaruh keunggulan produk dan keunggulan bersaing terhadap keputusan pembelian dengan citra merek sebagai vairabel intervening.

$\mathrm{H}_{3}$ : Keunggulan kompetitif berpengaruh signifikan terhadap keputusan pembelian.

Menurut Silvia, dkk.(2014) pemasaran hijau mempunyai prospek yang baik untuk dikembangkan sebagai pilihan metode pemasaran di era modern karena isu lingkungan hidup ini dapat membangun citra yang baik. Konsumen cenderung memberikan citra positif terhadap perusahaan yang mulai melakukan kegiatan yang berorientasi terhadap lingkungan. Suatu keunggulan kompetitif akan dimiliki oleh perusahaan yang memasarkan produk-produknya dengan karakteristik peduli terhadap lingkungan. Program marketing yang kuat terhadap produk tersebut dapat membangun citra merek yang positif. Dengan memiliki citra yang positif maka keuntungan besar bagi perusahaan karena konsumen akan mudah mengingat 
mereknya tersebut sehingga peluang konsumen untuk mengambil keputusan dalam membeli produk tersebut pun semakin besar.

Berdasarkan penelitian Silvia, dkk.(2014) menyatakan dengan mempertahankan green marketing pada Oriflame akan mampu menciptakan keunggulan kompetitif sehingga dapat meningkatkan citra merek yang secara tidak langsung berpengaruh pada peningkatan keputusan pembelian. Penelitian yang relevan lainnya yaitu Netty Laura (2017) dalam penelitiannya menemukan pengaruh keunggulan produk dan keunggulan bersaing terhadap keputusan pembelian dengan citra merek sebagai vairabel intervening.

$\mathrm{H}_{4}$ : Keunggulan kompetitif secara tidak langsung berpengaruh signifikan dalam memediasi green marketing terhadap keputusan pembelian.

\section{METODE PENELITIAN}

Berdasarkan penelitian terdahulu dan kajian teoritis yang sudah dipaparkan, maka kerangka pemikiran dalam penelitian ini adalah sebagai berikut:

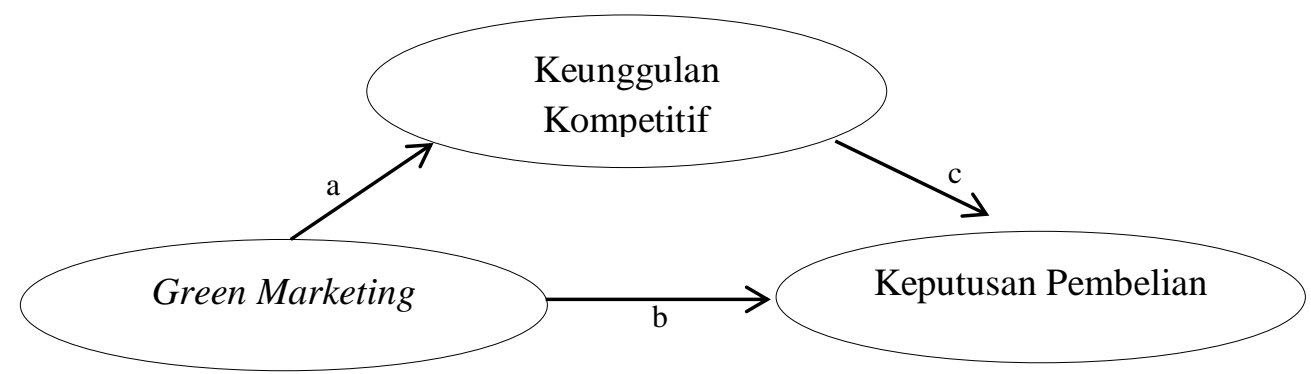

Gambar 1 Model Kerangka Berpikir

Sumber : Kajian Penelitian Sebelumnya

Desain Penelitian yang digunakan adalah penelitin asosiatif. Penelitian ini merupakan penelitian yang dalam pengujian untuk mengetahui pengaruh green marketing $\left(\mathrm{X}_{1}\right)$ terhadap keputusan pembelian $\left(\mathrm{Y}_{2}\right)$ yang dimediasi oleh 
Ida Bagus Ivan Satria Widiarsa, Peran Keunggulan Kompetitif Memediasi Pengaruh...]

keunggulan kompetitif (Y1). Lokasi dilakukannya penelitian adalah di Perusahaan yang bergerak pada bidang restoran dengan nama Earth Café Seminyak yang terletak di Kabupaten Badung.

Ruang lingkup penelitian yang terdapat pada penelitian ini adalah hanya pada green marketing, keunggulan kompetitif, dan keputusan pembelian pada Earth Café Seminyak. Dibatasinya penelitian yang dilakukan hanya pada variabel tersebut agar penelitian dapat berjalan fokus dan hasil yang diperoleh dapat lebih cepat. objek dalam penelitian ini adalah peran keunggulan kompetitif dalam memediasi pengaruh green marketing terhadap keputusan pembelian (Studi pada perusahaan Earth Café di Seminyak). Populasi yang digunakan adalah konsumen Earth Cafe. Jumlah sampel pada penelitian ini adalah 10 kali jumlah indikator yaitu $10 \times 9=90$.

Metode untuk menentukan sampel di dalam penelitian ini adalah dengan purposive sampling. Metode penentuan ini digunakan karena pengambilan anggota sampel dari populasi dilakukan secara acak tanpa memperhatikan strata yang ada dalam populasi itu (Sugiyono, 2014:118). Adapaun Kriteria yang dipergunakan dalam memilih responden yaitu responden yang sudah menggunakan produk di Earth Café di Seminyak dengan usia minimal 17 tahun. Data dalam penelitian ini di analisis menggunakan teknik analisis jalur (path analysis) dengan persamaan struktural sebagai berikut :

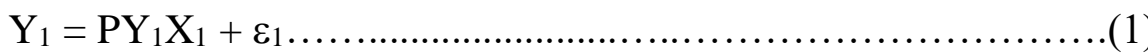

$$
\begin{aligned}
& \mathrm{Y}_{2}=\mathrm{PY}_{2} \mathrm{X}_{1}+\mathrm{PY}_{2} \mathrm{Y}_{1}+\varepsilon
\end{aligned}
$$


Untuk menguji signifikansi kepuasan pelanggan sebagai variabel mediator dalam pengaruh antara variabel komunitas merek dan variabel loyalitas pelanggan, maka digunakan Uji Sobel. Uji Sobel dirumuskan sebagai berikut.

$$
\mathrm{Z}=\frac{}{\sqrt{b^{2} s_{a}^{2}+a^{2} s_{b}^{2}+s_{a}^{2} s_{b}^{2}}}
$$

Keterangan:

$\mathrm{a}=$ koefisien regresi dari variabel independen $(\mathrm{X})$ terhadap variabel moderator (M).

$\mathrm{S}_{\mathrm{a}}=$ standar error dari $\mathrm{a}$.

$\mathrm{b}=$ koefisien regresi dari variabel moderator $(\mathrm{M})$ terhadap variabel dependen (Y).

$\mathrm{S}_{\mathrm{b}}=$ standar error dari $\mathrm{b}$.

\section{HASIL DAN PEMBAHASAN}

Earth Cafe merupakan sebuah usaha kuliner yang bergerak pada industri restoran yang berdiri di pertengahan tahun 2006 .Earth café menerapkan konsep green resto family bergaya tradisional Bali dikombinasikan dengan konsep natural indoor dan outdoor.

Saat ini, Earth cafe tidak hanya dijadikan tempat untuk bersantap saja tetapi juga dijadikan sebagai sarana untuk berkumpul dan bersosialisasi, tempat untuk menggelar pertemuan dengan rekan bisnis. Earth cafe melihat keadaan ini sebagai peluang untuk membuat bisnis mereka menjadi lebih berkembang. Oleh karena itu, Earth Cafe tidak hanya menawarkan berbagai macam keuntungan dan fasilitas lainnya seperti suasana yang nyaman dan santai serta ditambahkan fasilitas penggu naan internet gratis bagi para konsumen menyediakan makanan, minuman, cemilan untuk vegetarian dan vegan yg terbuat dari bahan-bahan 
Ida Bagus Ivan Satria Widiarsa, Peran Keunggulan Kompetitif Memediasi Pengaruh...]

organic. Alamat: J1. Kayu Aya No.99, Seminyak, Kuta Utara, Kabupaten Badung, Bali 80361

Dari hasil penelitian yang dilakukan terhadap konsumen Earth Café di Seminyak, dapat diketahui gambaran tentang karakteristik responden yang meliputi jenis kelamin, umur, frekuensi kunjungan dan tingkat pendidikan.

Tabel 1 Karakteristik Responden

\begin{tabular}{ccccc}
\hline No & Karakteristik & Kategori & Jumlah (Orang) & Persentase (\%) \\
\hline $\mathbf{1}$ & Jenis kelamin & Laki-laki & 40 & 44,4 \\
& & Perempuan & 50 & 55,6 \\
\hline $\mathbf{2}$ & Umur & $17-35 \mathrm{Th}$ & 10 & 11,1 \\
& $36-45 \mathrm{Th}$ & 60 & 66,7 \\
& $46-55 \mathrm{Th}$ & 15 & 16,7 \\
& $>55 \mathrm{Th}$ & 5 & 5,6 \\
\hline $\mathbf{3}$ & Frekuensi kunjungan & $3 \mathrm{kali}$ & 10 & 11,1 \\
& & $4 \mathrm{kali}$ & 50 & 55,6 \\
& $5 \mathrm{kali}$ & 20 & 22,2 \\
& & $>5 \mathrm{kali}$ & 0 & 0 \\
\hline $\mathbf{4}$ & SLTA & 5 & 5,6 \\
& Pendidikan & S1 & 70 & 27,8 \\
& & $\mathrm{~S} 2$ & 25 & 100 \\
\hline
\end{tabular}

Tabel 1 menunjukkan bahwa ditinjau dari jenis kelamin, dapat diketahui bahwa konsumen Earth Café sebagian besar adalah perempuan yaitu sebanyak 55,6 persen, pada umumnya wanita berkeinginan mengkonsumsimenu yang sehat yang segar untuk kesehatan dirinya. Ditinjau dari klasifikasi umur yang berkunjung ke Earth Café diperoleh pada rentangan 36-45 tahun merupakan kelompok responden yang tertinggi, hal tersebut disebabkan karena kelompok usia tersebut merupakan kelompok produktif secara ekonomi. Dilihat dari frekuensi kunjungan yang telah dilakukan oleh responden, ditemukan sebagian besar telah berkunjung sebanyak 4 kali, hal ini menandakan bahwa Earth Café memiliki nama yang cukup berkesan dihati pelanggannya sehingga konsumen 
tersebut melakukan pembelian ulang. Berdasarkan tingkat pendidikan dapat diketahui bahwa pengunjung Earth Café sebagian besar berpendidikan S1 (77,8\%) hal ini menandakan bahwa konsumen Earth Café berpendidikan tinggi yang sudah memahami arti pentingnya kesegaran dan menu green bagi kesehatan dirinya.

Uji validitas digunakan untuk mengukur sah atau valid tidaknya suatu kuesioner. Suatu kuesioner dikatakan valid jika pertanyaan pada kuesioner mampu untuk mengungkapkan sesuatu yang akan diukur oleh kuesioner tersebut. Uji validitas pada penelitian ini dilakukan terhadap variabel green marketing, keunggulan kompetitif dan keputusan pembelian.

Tabel 2 Hasil Uji Validitas Variabel Penelitian

\begin{tabular}{cccc}
\hline No & Pernyataan & Koefisien Korelasi & Valid \\
\hline $\mathbf{1}$ & X.1 & 0,938 & Valid \\
$\mathbf{2}$ & X.2 & 0,955 & Valid \\
$\mathbf{3}$ & X.3 & 0,863 & Valid \\
$\mathbf{3}$ & Y1.1 & 0,713 & Valid \\
$\mathbf{4}$ & Y1.2 & 0,797 & Valid \\
$\mathbf{5}$ & Y1.3 & 0,786 & Valid \\
$\mathbf{6}$ & Y2.1 & 0,798 & Valid \\
$\mathbf{7}$ & Y2.2 & 0,765 & Valid \\
$\mathbf{8}$ & Y2.3 & 0,676 & Valid \\
\hline
\end{tabular}

Sumber: Data Primer Diolah, 2018

Berdasarkan Tabel 2 diketahui bahwa seluruh indikator dalam variabel green marketing, keunggulan kompetitif dan keputusan pembelian memiliki koefisien korelasi yang lebih besar dari 0,3. Jadi dapat disimpulkan bahwa seluruh indikator telah memenuhi syarat validitas data.

Kemudian, untuk mengukur reliabilitas dalam penelitian ini menggunakan uji statistik cronbach alpha dengan nilai lebih besar dari 0,60. Reliabilitas adalah alat untuk mengukur suatu kuesioner yang merupakan indikator dari variabel atau 
Ida Bagus Ivan Satria Widiarsa, Peran Keunggulan Kompetitif Memediasi Pengaruh...]

konstruk. Suatu kuesioner dikatakan reliabel atau handal jika jawaban seseorang terhadap pernyataan adalah konsisten atau stabil dari waktu ke waktu. Hasil uji reliabilitas dalam penelitian ini ditunjukkan pada tabel 3 berikut.

Tabel 3 Uji Reliabilitas

\begin{tabular}{lcl}
\hline \multicolumn{1}{c}{ Variabel } & Alpa Cronbach & Keterangan \\
\hline Kualitas pelayanan & 0,905 & Reliabel \\
Keunggulan kompetitif & 0,646 & Reliabel \\
Keputusan pembelian & 0,602 & Reliabel \\
\hline Sumber: Data Primer Diolah, 2018 & &
\end{tabular}

Hasil uji pada Tabel 3 menunjukkan nilai cronbach alpha untuk semua variabel diatas 0,6 . Sehingga dapat disimpulkan bahwa semua variabel telah memenuhi syarat reliabilitas data.

Jumlah responden yang dijadikan sampel dalam penelitian ini pada Earth Cafe sebanyak 90 orang. Penelitian dilakukan dengan mengajukan kuesioner dimana variabel green marketing terdiri dari 3 pernyataan, keunggulan kompetitif sebanyak 3 pernyataan dan keputusan pembelian sebanyak 3 pernyataan.

Distribusi penilaian responden pada Earth Cafe di Denpasar, mengenai green marketing $(\mathrm{X})$ dapat dilihat pada Tabel 4 sebagai berikut.

Tabel 4 Distribusi Tanggapan Responden Tentang Green Marketing

\begin{tabular}{|c|c|c|c|c|c|c|c|c|}
\hline \multirow[t]{2}{*}{ Indikator } & \multicolumn{5}{|c|}{ Skor Jawaban } & \multirow{2}{*}{$\begin{array}{c}\text { Jumlah } \\
\text { Skor }\end{array}$} & \multirow{2}{*}{$\begin{array}{l}\text { Rata- } \\
\text { Rata }\end{array}$} & \multirow[t]{2}{*}{ Ket } \\
\hline & 1 & 2 & 3 & 4 & 5 & & & \\
\hline Promosi penjualan & & & 28 & 59 & 3 & 335 & 3,72 & Baik \\
\hline Peralatan dan fasilitas & & & 25 & 62 & 3 & 338 & 3,76 & Baik \\
\hline Kenyamanan & & & 25 & 59 & 6 & 341 & 3,79 & Baik \\
\hline
\end{tabular}

Sumber: Data Primer Diolah, 2018

Berdasarkan Tabel 4 terlihat bahwa rata-rata skor dari 3 pernyataan mengenai green marketing yaitu sebesar 3,76. Hal ini berarti konsumen yang menjadi responden dalam penelitian ini menilai green marketing Earth Cafe 
adalah baik.Indikator yang bernilai dibawah nilai rata-rata variabel yaitu promosi penjualan $(3,72)$, hal ini menunjukkan bahwa promosi penjualan yang dilakukan oleh Earth Cafe masih dianggap kurang oleh responden, sehingga jarang pelanggan mengetahui produk unggulan maupun program discount yang diberikan oleh pihak Earth Cafe.

Distribusi penilaian responden pada Earth Cafe di Denpasar, mengenai keunggulan kompetitif $\left(\mathrm{Y}_{1}\right)$ dapat dilihat pada Tabel 5 sebagai berikut.

Tabel 5 Distribusi Tanggapan Responden Pada Keunggulan Kompetitif

\begin{tabular}{lllllllll}
\hline Indikator & \multicolumn{4}{c}{ Skor Jawaban } & Jumlah & Rata- & Ket \\
& 1 & 2 & 3 & 4 & 5 & Skor & Rata & \\
\hline Keunikan produk & 1 & 4 & 83 & 2 & 356 & 3,96 & Baik \\
Kualitas produk & 1 & 8 & 79 & 2 & 352 & 3,91 & Baik \\
Harga bersaing & & 9 & 79 & 2 & 353 & 3,92 & Baik \\
\hline Rata-rata & & & & & & 3,93 & Baik \\
\hline Sumber: Data Primer Diolah, 2018 & & & & & & &
\end{tabular}

Berdasarkan Tabel 5 terlihat bahwa rata-rata skor dari 3 pernyataan mengenai keunggulan kompetitif yaitu sebesar 3,93. Hal ini berarti tamu yang menjadi responden dalam penelitian ini menilai keunggulan kompetitif adalah baik. Indikator yang bernilai dibawah nilai rata-rata adalah kualitas produk $(3,91)$ dan harga bersaing $(3,92)$. Banyaknya kompetitor yang ada disekitar Earth Cafe terkadang menawark harga yang lebih murah dan produk yang serupa, membuat konsumen Earth Cafe tergiur untuk mencoba produk dari kompetitor.

Distribusi penilaian responden pada Earth Cafe di Denpasar, mengenai keputusan pembelian $\left(\mathrm{Y}_{2}\right)$ dapat dilihat pada Tabel 6 sebagai berikut. 
Tabel 6 Distribusi Tanggapan Responden Pada Keputusan Pembelian ( $\left.\mathrm{Y}_{2}\right)$

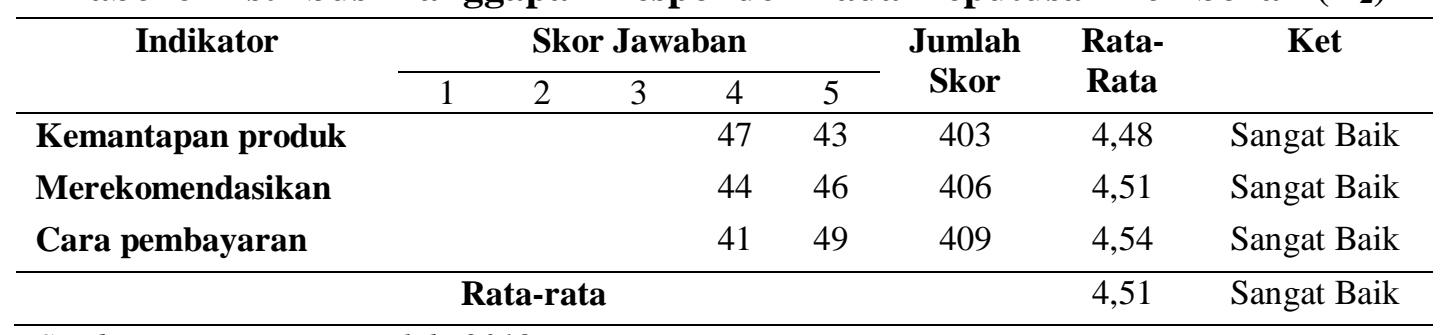

Sumber: Data Primer Diolah, 2018

Berdasarkan Tabel 6 terlihat bahwa rata-rata skor dari 3 pernyataan mengenai keputusan pembelian yaitu sebesar 4,51 yang berada pada kisaran 4,21 - 5,00 yang berarti sangat baik. Hal ini berarti konsumen yang menjadi responden dalam penelitian ini menilai keputusan pembelian adalah sangat baik. Sedangkan indikator yang bernilai kurang dari nilai rata-rata adalah kemantapan produk $(4,48)$. Kemantapan produk yang dijual Earth Cafe tidak dipajang di ruang depan dengan pertimbangan kenyamanan dan keindahan tempat, sehingga ditempatkan di bagian belakang membuat konsumen sedikit ragu dengan jaminan kesegaran bahan yang digunakan.

Untuk memperoleh skor regresi faktor untuk masing-masing variabel yang digunakan dalam penelitian maka dilakukan uji analisis faktor. Berikut ini disajikan hasil analisis faktor berdasarkan tahapan yang ada dalam analisis faktor. Langkah pertama yaitu matriks korelasi. Matriks korelasi digunakan untuk mengidentifikasikan variabel-variabel tertentu yang tidak mempunyai korelasi dengan variabel lain, sehingga dapat dikeluarkan dari analisis. Koefisien matriks korelasi disajikan pada Tabel 7. 
Tabel 7 Koefisien Matriks Korelasi Pada Keempat Variabel Penelitian

\begin{tabular}{clc}
\hline No. & \multicolumn{1}{c}{ Variabel } & Determinan \\
\hline 1. & Green marketing & 0,061 \\
1. & Keunggulan kompetitif & 0,664 \\
3. & Keputusan pembelian & 0,688
\end{tabular}

Sumber : Data Primer Diolah, 2018

Berdasarkan Tabel 7, koefisien determinasi dari masing-masing variabel sudah mendekati nilai 0. Jadi dapat dinyatakan bahwa, item instrumen dari masing-masing variabel memiliki korelasi yang kuat.

Langkah kedua adalah uji Kaiser Meyer Olkin (KMO) untuk mengetahui kecukupan sampelnya. Analisis faktor dianggap layak jika besaran KMO nilainya minimal 0,5. Hasil uji Kaiser Meyer Olkin (KMO) disajikan pada Tabel 8

\section{Tabel 8 Hasil Uji Kaiser Meyer Olkin ( KMO )}

\begin{tabular}{clc}
\hline No. & \multicolumn{1}{c}{ Variabel } & KMO \\
\hline $\mathbf{1 .}$ & Green marketing & 0,667 \\
1. & Keunggulan kompetitif & 0,639 \\
3. & Keptuusan pembelian & 0,587 \\
\hline \multicolumn{2}{l}{ Sumber : Data Primer Diolah, 2018 }
\end{tabular}

Berdasarkan Tabel 8, nilai Kaiser Meyer Olkin (KMO) untuk masingmasing variabel lebih besar dari 0,5 dengan signifikansi lebih kecil dari alpha 5 persen. Jadi dapat dinyatakan bahwa, masing-masing variabel memiliki kecukupan sampel untuk melakukan analisis faktor.

Kelayakan model uji faktor untuk masing-masing variabel dapat dilihat dari nilai Measures of Sampling Adequancy (MSA). Dalam penelitian ini, variabel terikatnya adalah variabel green marketing, keunggulan kompetitif, dan keputusan pembelian. Berikut nilai MSA instrumen dari masing-masing variabel disajikan pada Tabel 9. 
Tabel 9 Nilai Measures of Sampling Adequancy ( MSA )

\begin{tabular}{ccc}
\hline Variabel & Faktor & MSA \\
\hline Green marketing & X1 & 0,624 \\
& X2 & 0,604 \\
Keunggulan kompetitif & Y1.1 & 0,893 \\
& Y1.2 & 0,689 \\
& Y1.3 & 0,629 \\
Keputusan pembelian & Y2.1 & 0,612 \\
& Y2.2 & 0,561 \\
& Y2.3 & 0,572 \\
& & 0,706
\end{tabular}

Sumber : Data Primer Diolah, 2018

Berdasarkan Tabel 9, nilai MSA instrumen dari masing-masing variabel lebih besar dari 0,5. Jadi dapat dinyatakan bahwa, masing-masing model layak digunakan dalam model uji faktor. Kemudian nilai Percentage of Variance untuk masing-masing variabel disajikan pada Tabel 10

\section{Tabel 10 Nilai Percentage of Variance}

\begin{tabular}{clc}
\hline No. & \multicolumn{1}{c}{ Variabel } & Percentage of Variance \\
\hline 1. & Green marketing & 84,615 \\
1. & Keunggulan kompetitif & 58,749 \\
3. & Keputusan pembelian & 56,169 \\
\hline
\end{tabular}

Sumber : Data Primer Diolah, 2018

Berdasarkan Tabel 10, nilai Percentage of Variance untuk masing-masing variabel lebih besar dari 50 persen. Jadi dapat dinyatakan bahwa, faktor-faktor dari masing-masing variabel memiliki kelayakan kemampuan untuk menjelaskan variasi faktornya.

Pengujian rotasi faktor penelitian ini menggunakan rotasi Varimax. Adapun hasil dari rotasi faktor untuk masing-masing variabel dapat ditunjukkan pada Tabel 11. 
Tabel 11 Rotasi Faktor dengan Metode Varimax

\begin{tabular}{ccc}
\hline Variabel & Faktor & Nilai Rotasi Faktor (Varimax Method ) \\
\hline Y2 & Y2.1 & 0,829 \\
& Y2.2 & 0,791 \\
& Y2.3 & 0,611 \\
Y1 & $\mathrm{Y}_{1.1}$ & 0,711 \\
& $\mathrm{Y}_{1.2}$ & 0,780 \\
& $\mathrm{Y}_{1.3}$ & 0,806 \\
$\mathrm{X} .1$ & $\mathrm{X} .1$ & 0,948 \\
& $\mathrm{X} .2$ & 0,963 \\
& $\mathrm{X} .3$ & 0,844
\end{tabular}

Sumber : Data Primer Diolah, 2018

Berdasarkan Tabel 11 dapat ditunjukkan bahwa, seluruh instrumen dari masing-masing variabel telah memenuhi syarat dan menunjukkan korelasi yang kuat.Hal ini dapat dilihat dari nilai rotasi yang lebih besar dari 0,40.

Pengujian data pada penelitian ini menggunakan analisis jalur (path analysis) guna menguji pola hubungan yang mengungkapkan pengaruh variabel atau seperangkat variabel terhadap variabel lainnya, baik pengaruh langsung maupun pengaruh tidak langsung. Model jalur peran keunggulan kompetitif dalam memediasi pengaruh green marketing terhadap keputusan pembelian dalam penelitian ni disajikan pada gambar berikut.

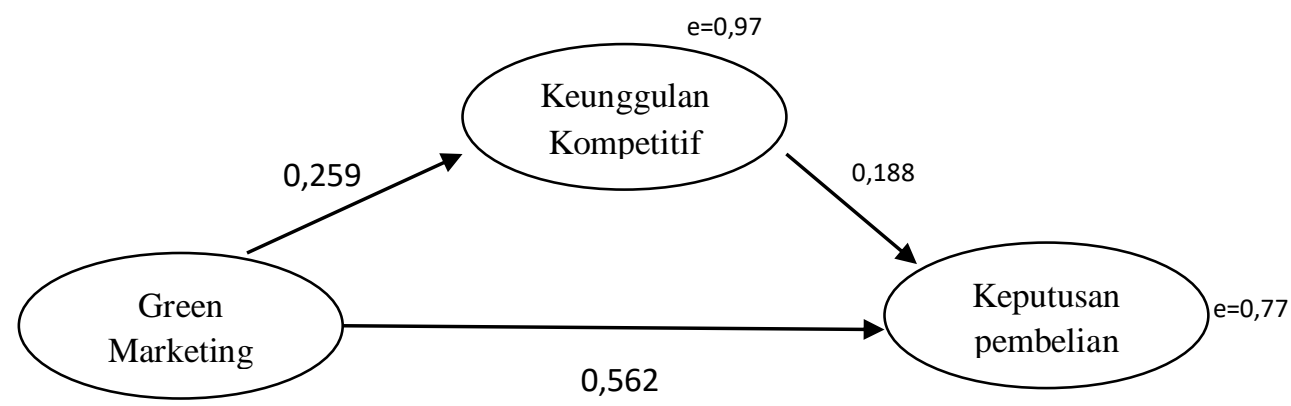

Gambar 2 Model Diagram Jalur

Sumber : Data Primer Diolah, 2018 
Ida Bagus Ivan Satria Widiarsa, Peran Keunggulan Kompetitif Memediasi Pengaruh...]

Gambar 2 menunjukkan bahwa nilai koefisien jalur model green marketing terhadap keputusna pembelian melalui keunggulan kompetitif. Berdasarkan informasi pada gambar 2 diketahui bahwa koefisien jalur pengaruh keunggulan kompetitif sebesar 0,188 tidak bernilai nol (0) ,yang berarti persepsi keunggulan kompetitif memediasi pengaruh positif green marketing terhdap keputusan pemebelian pada Earth Café.

Output hasil SPS hasil pengujian penggaruh variabel green marketing terhadap keunggulan kompetitif disajikan berdasarkan persamaan strukturnya adalah sebagai berikut:

$$
\mathrm{Y}_{1}=0,259 \mathrm{X}
$$

Perhitungan nilai standar error sebagai berikut:

$$
\text { Pei }=\sqrt{ } 1-0,067=0,97
$$

Output hasil SPS hasil pengujian penggaruh variabel keunggulan kompetitif terhadap keputusan pembelian disajikan berdasarkan persamaan strukturnya adalah sebagai berikut:

$$
\mathrm{Y}_{2}=0,562 \mathrm{X}+0,188 \mathrm{Y}_{1}
$$

Perhitungan nilai standar error sebagai berikut:

$$
\text { Pei }=\sqrt{ } 1-0,406=0,77
$$

Hasil koefisien determinasi total :

$$
\begin{aligned}
& \mathrm{R}^{2}{ }_{\mathrm{m}}=1-(1-0,067)(1-0,406) \\
& \mathrm{R}_{\mathrm{m}}{ }=1-0,55 \\
& \mathrm{R}_{\mathrm{m}}=0,45
\end{aligned}
$$


Artinya, keragaman data yang dapat dijelaskan oleh model adalah sebesar 45 persen atau dengan kata lain informasi yang terkandung dalam data sebesar 45 persen dapat dijelaskan oleh model, sedangkan sisanya yaitu 55 persen dijelaskan oleh variabel lain (tidak terdapat dalam model) dan error.

Untuk menguji variabel mediator yang memediasi hubungan antara variabel terikat dengan variabel bebas digunakan analisis uji sobel dengan hasil perhitungan diperoleh $\mathrm{Z}_{\text {hitung }}(2,12)>\mathrm{Z}_{\text {tabel }}(1,96)$ sehingga $\mathrm{H} 0$ ditolak dan $\mathrm{H}_{4}$ diterima, dengan kata lain keunggulan kompetitif merupakan variabel intervening yang menghubungkan green marketing dengan keputusan pembelian pada Earth Café.

Berdasarkan perhitungan terhadap substruktur 1, dan 2, maka dapat diketahui besarnya pengaruh langsung, pengaruh tidak langsung dan pengaruh total antar variabel. Perhitungan pengaruh antar variabel adalah sebagai berikut.

Tabel 12 Pengaruh Langsung, Pengaruh Tidak Langsung \& Pengaruh Total

\begin{tabular}{|c|c|c|c|c|c|}
\hline Variabel & & & $\begin{array}{l}\text { Pengaruh } \\
\text { langsung }\end{array}$ & $\begin{array}{c}\text { Pengaruh } \\
\text { Tidak langsung } \\
\text { melalui keunggulan } \\
\text { kompetitif } \\
\end{array}$ & $\begin{array}{c}\text { Jumlah } \\
\text { Pengaruh } \\
\text { Total }\end{array}$ \\
\hline $\begin{array}{l}\text { Green } \\
\text { marketing }\end{array}$ & $\rightarrow$ & $\begin{array}{l}\text { Keunggulan } \\
\text { kompetitif }\end{array}$ & 0,259 & & 0,259 \\
\hline $\begin{array}{l}\text { Keunggulan } \\
\text { kompetitif }\end{array}$ & $\rightarrow$ & $\begin{array}{l}\text { Keputusan } \\
\text { pembelian }\end{array}$ & 0,188 & & 0,188 \\
\hline $\begin{array}{l}\text { Green } \\
\text { marketing }\end{array}$ & $\rightarrow$ & $\begin{array}{l}\text { Keputusan } \\
\text { pembelian }\end{array}$ & 0,562 & 0,044 & 0,606 \\
\hline
\end{tabular}

Berdasarkan hasil pengujian empiris diperoleh taraf signifikansi penelitian untuk variabel green marketing terhadap keunggulan kompentitif sebesar $0,014<$ 0,05, sehingga H0 ditolak dan H1 diterima, dengan kata lain green marketing berpengaruh signifikan terhadap keunggulan kompetitif. Hasil penelitian 
Ida Bagus Ivan Satria Widiarsa, Peran Keunggulan Kompetitif Memediasi Pengaruh...]

menunjukkan semakin baik green marketing maka keunggulan kompetitif semakin meningkat.

Pemasaran hijau (green marketing) adalah proses penyusunan komunikasi terpadu yang bertujuan untuk memberikan informasi mengenai barang atau jasa dalam kaitannya dengan memuaskan kebutuhan dan keinginan manusia dengan cara yang sesuai untuk menjaga lingkungan. Berdasarkan Rachmawati (2011) dukungan faktor-faktor bauran pemasaran (marketing mix) mampu menciptakan nilai yang lebih bagi pelanggan yang berimbas kepada loyalitas pelanggan. Dengan adanya loyalitas pelanggan, maka akan mampu meningkatkan pendapatan pengusaha dibidang restoran.

Berdasarkan hasil pengujian secara empirik diperoleh taraf signifikansi penelitian untuk variabel green marketing terhadap keputusan pembelian sebesar $0,000<0,05$, sehingga $\mathrm{H} 0$ ditolak dan $\mathrm{H} 2$ diterima, dengan kata lain green marketing berpengaruh signifikan terhadap keputusan pembelian. Hasil penelitian menunjukkan semakin tinggi keunggulan kompetitif maka semakin cepat keputusan pembelian dilakukan.

Agustina, dkk. (2016) konsep pemasaran hijau mencakup karakteristik tertentu seperti pemasaran produk yang aman bagi lingkungan, pengembangan dan pemasaran produk yang dapat meminimalkan bahaya bagi lingkungan, memproduksi, mempromosikan, dan mengemas produk dengan cara yang sesuai sehingga dapat melindungi lingkungan. Pemasaran hijau terdiri dari berbagai kegiatan usaha yang bertujuan untuk memenuhi kebutuhan dan keinginan konsumen, serta mengurangi dampak negatif pada lingkungan alam. Pemasaran 
hijau dalam penerapannya di perusahaan mengadopsi empat elemen bauran pemasaran (marketing mix) antara lain: product, price, place, dan promotion.Keputusan pembelian salah satunya dipengaruhi oleh marketing mix yang dilakukan oleh perusahaan. Keputusan pembelian konsumen adalah membeli merek yang paling disukai. Pengambilan keputusan konsumen adalah suatu proses integrasi yang dipergunakan untuk mengkombinasikan pengetahuan dengan tujuan mengevaluasi dua atau lebih perilaku alternatif dan memilih satu diantaranya. Berdasarkan penelitian dari Septifani,dkk. (2014) menyatakan bahwa teh dalam kemasan yang menerapkan konsep green marketing dengan menggunakan kemasan RGB (Returnable Glass Bottling) mampu meningkatkan keputusan pembelian konsumen yang memang sadar lingkungan. Berdasarkan pendapat tersebut, dapat disimpulkan bahwa keputusan pembelian merupakan penetapan pilihan konsumen melalui berbagai alternatif pilihan produk.

Berdasarkan hasil pengujian secara empiris diperoleh taraf signifikansi penelitian untuk variabel keunggulan kompetitif terhadap keputusan pembeliansebesar $0,031<0,05$, sehingga $\mathrm{H} 0$ ditolak dan $\mathrm{H} 3$ diterima, dengan kata lain keunggulan kompetitif berpengaruh signifikan terhadap keputusan pembelian.Hasil penelitian menunjukkan semakin tinggi keunggulan kompetitif maka semakin cepat keputusan pembelian.

Keunggulan kompetitif merujuk pada kemampuan sebuah organisasi untuk memformulasikan strategi yang menempatkannya pada suatu posisi yang menguntungkan dibandingkan perusahaan lainnya. Untuk meningkatkan keunggulan kompetitif dapat dilakukan dengan kebijakan harga yang kompetitif, 
Ida Bagus Ivan Satria Widiarsa, Peran Keunggulan Kompetitif Memediasi Pengaruh...]

promosi dan kualitas pelayanan. Berdasarkan hasil penelitian Weenas (2013) menyatakan bahwa dengan meningkatkan kualitas pelayanan, promosi serta menerapkan harga yang terjangkau pada PT. Massindo Sinar Pratama dapat meningkatkan keputusan pembelian dari konsumen.

Berdasarkan hasil perhitungan diperoleh $\mathrm{Z}_{\text {hitung }}(2,12)>\mathrm{Z}_{\text {tabel }}(1,96)$ sehingga $\mathrm{H} 0$ ditolak dan $\mathrm{H}_{4}$ diterima, dengan kata lain keunggulan kompetitif merupakan variabel intervening yang menghubungkan green marketing dengan keputusan pembelian pada PT. Satwika Purwa Negara.

Menurut Silvia, dkk. (2014) pemasaran hijau mempunyai prospek yang baik untuk dikembangkan sebagai pilihan metode pemasaran di era modern karena isu lingkungan hidup ini dapat membangun citra yang baik. Konsumen cenderung memberikan citra positif terhadap perusahaan yang mulai melakukan kegiatan yang berorientasi terhadap lingkungan. Suatu keunggulan kompetitif akan dimiliki oleh perusahaan yang memasarkan produk-produknya dengan karakteristik peduli terhadap lingkungan. Program marketing yang kuat terhadap produk tersebut dapat membangun citra merek yang positif. Dengan memiliki citra yang positif maka keuntungan besar bagi perusahaan karena konsumen akan mudah mengingat mereknya tersebut sehingga peluang konsumen untuk mengambil keputusan dalam membeli produk tersebut pun semakin besar.

\section{SIMPULAN DAN SARAN}

Simpulan yang dapat diberikan berdasarkan hasil penelitian dapat disimpulkan yaitu green marketing berpengaruh signifikan terhadap keunggulan 
kompetitif pada Earth Café Seminyak. Green marketing berpengaruh signifikan terhadap keputusan pembelian pada Earth Café Seminyak. Keunggulan kompetitif berpengaruh signifikan terhadap keputusan pembelian pada Earth Café Seminyak. Keunggulan kompetitif dapat memediasi pengaruh green marketing terhadap keputusan pembelian pada Earth Café Seminyak.

Adapun saran yang dapat diberikan berdasarkan hasil penelitian yaitu pada variabel green marketing Earth Cafe promosi didapat indikator promosi penjualan masih dibawah nilai rata-rata variabel, oleh karena itu pihak managemen sebaiknya melakukan promosi pada media sosial yang berorientasi pada komunitas yang menyukai kuliner. Pada keunggulan kompetitif didapat kualitas produk dengan respon terendah dibandingkan dengan indikator yang lain, untuk itu perlu dilakukan terobosan baru terutama pada keunikan menu yang ditawarkan.harga bersaing dengan nilai rata-rata terendah, untuk itu pihak managemen meninjau kembali harga jual produk yang dijual, agar tidak terlalu jauh berbeda dengan produk yang dijual oleh kompetitor. Earth Cafe sebagai produsen harus mempertahankan nama baik dalam segi kualitas produk melalui bahan terpercaya, terbaik sehingga konsumen meeasa nyaman dan bahagia jika melakukan pembelian pada Earth Cafe di Seminyak. 


\section{REFERENSI}

Adji, Pricilia dan Hartono Subagio. 2013. Pengaruh Retail Mix Terhadap Keputusan Pembelian Mahasiswa UK Petra di Circle K Siwalankerto Surabaya. Jurnal Manajemen Pemasaran Petra, Vol. 1(2), h:1-10.

Burja, Vasile. 2012. Environmental Management System and Companies' Sustainable Performance In Romania. Annales Universitatis Apulensis: Series Oeconomica, Vol. 14(1), pp: 226-235

Djodjobo, Cynthia Vanessa dan Tawas, Hendra N. 2014. Pengaruh Orientasi Kewirausahaan, Inovasi Produk, dan Keunggulan Bersaing Terhadap Kinerja Pemasaran Usaha Nasi Kuning di Kota Manado. Jurnal EMBA, Vol. 2(3), h: 1214-1224.

Haryanto, Joko Tri dan Olivia. 2014. Theoritical Review of The Application of Green Banking in Indonesia. Jurnal ekonomi, Vol. 16(2), pp: 166.

Indriantoro, Nur dan Bambang Supomo.2014.Metode Penelitian Bisnis Untuk Akutansi dan Manajemen. Yogyakarta: BPFE.

Kinoti, Mary Wanjiru. 2011. Green Marketing Intervention Strategies And Sustainable Development: A Conceptual Paper. International Journal of Business and Social Science. Vol. 2(23), pp: 263-273.

Kotler, Philip dan Kevin Lane Keller. 2009. Manajemen Pemasaran. Edisi 13, Jilid 1 dan 2. Jakarta: Erlangga.

Parawitha, IGM Danendra Dharma, dan Ni Made Rastini. 2016. Pengaruh Strategi Green Marketing, Corporate Social Marketing dan Environmental Behavior Terhadap Green Purchasing Behavior. E-Jurnal Manajemen Unud, Vol. 5 (10), h:6457-6486.

Rahcmawati, Rina. 2011. Peranan Bauran Pemasaran (Marketing Mix) Terhadap Peningkatan Penjualan (Sebuah Kajian Terhadap Bisnis Restoran).Jurnal Kompetensi Teknik, Vol. 2(2), h:143-150.

Reed, Richard, David J. Lemak, and Neal P. Mero. 2000. Total Quality Management and Sustainable Competitive Advantage. Journal of Quality Management, Vol. 5(1), pp: 5-26.

Rejeki, Denik Sri, dkk. 2015. Pengaruh Green Marketing Pada Keputusan Pembelian dan Implikasinya Terhadap Loyalitas Pelanggan. Jurnal Administrasi Bisnis. Vol. 26(1), h: 1-7.

Romadon, Yusuf, Srikandi Kumadji, dan Yusri Abdillah. 2014. Perngaruh Green Marketing Terhadap Brand Image dan Struktur Keputusan Pembelian 
(Survei Pada Followers Account Twitter @PertamaxIND Pengguna Bahan Bakar Ramah Lingkungan Pertamax Series). Jurnal Administrasi Bisnis, Vol. 15(1), h:1-7.

Sani, Aprilianto Andry. 2017. Pengaruh Teknologi Ramah Lingkungan dan Kualitas Pelayanan Terhadap Keunggulan Kompetitif dan Kinerja Perusahaan.Skripsi Jurusan Manajemen Pada Fakultas Ekonomi dan Bisnis Universitas Udayan, Bali.

Shaputra, Rizky Kharismawan. 2013. Penerapan Green Marketing Pada Bisnis Produk Kosmetik.JurnalJIBEKA, Vol. 7(3), h: 47-53.

Silvia, Fadilatul, Achmad Fauzi D.H., dan Andriani Kusumawati. 2014. Pengaruh Pemasaran Hijau Terhadap Citra Merek Serta Dampaknya Pada Keputusan Pembelian (Survey Pada Konsultan Independen di Oriflame Cabang Surabaya). Jurnal Administrasi Bisnis(JAB), Vol. 14(1), h:1-9.

Siswanto, Bambang. 2010. Perkembangan Konsep dan Penelitian Green Marketing: Analisis Pustaka. Jurnal Ilmiah Manajemen Bisnis, Vol. 10(1), h: 63-70.

Situmorang, James R. 2011. Pemasaran Hijau Yang Semakin Menjadi Kebutuhan Dalam Dunia Bisnis.Jurnal Administrasi Bisnis, Vol. 7(2), h: 134.

Sueb, Memed dan Keraf, Maria.2012. Relasi Sistem Manajemen Lingkungan ISO 14001 dan Kinerja Keuangan.JDM, Vol. 3(1), h: 70.

Suendro, Ginanjar. 2010. Analisis Pengaruh Inovasi Produk Melalui Kinerja Pemasaran Untuk Mencapai Keunggulan Bersaing Berkelanjutan. Tesis Jurusan Manajemen Fakultas Ekonomi Universitas Diponogoro, Semarang.

Sugiyono. 2014. Metode Penelitian Bisnis. Bandung: Alfabeta.

Sulistyandari, dan Sri Retno Handayani. 2013. Membangun Keunggulan Bersaing Berkelanjutan: Sebuah Kajian Literatur Pada Konteks Usaha Kecil dan Menengah. Sustainable Competitive Advantage, Vol. 1(1), h: 1-17.

Weenas, Jackson R.S. 2013. Kualitas Produk, Harga, Promosi dan Kualitas Pelayanan Pengaruhnya Terhadap Keputusan Pembelian Spring Bed Comforta. Jurnal EMBA, Vol. 1(4), h:607-618.

Yamin, Shahid, A. Gunasekaran, and Felix T Mavondo. 1999. Relationship Between Generic Strategies, Competitive Advantage and Organizational Performance: An Emperical Analysis. Technovation, Vol. 19(8), pp: 507518. 